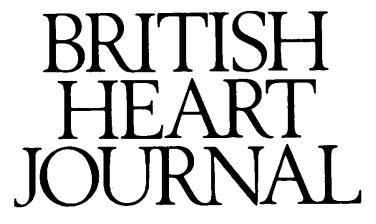

Editorial

\title{
Are streptokinase antibodies clinically important?
}

Streptokinase is produced by steptococci and when it is used therapeutically it reacts with existing antibodies produced in response to previous streptococcal infections and present in most patients. Streptokinase administered to patients will also provoke an immune response leading to the production of specific streptokinase antibodies. Streptokinase antibodies may affect a subsequently administered dose of streptokinase either by provoking an allergic reaction or by neutralising the streptokinase, rendering it ineffective and thus causing a failure of thrombolysis. These allergic reactions tend to be mild and not life threatening. ${ }^{12} \mathrm{Up}$ to $20 \%$ of patients in a large multicentre study of thrombolysis had had a previous infarct, and repeat administration of streptokinase when it was likely the patients still had high titres of antibodies to streptokinase did not have any life threatening allergic reactions. ${ }^{2}$ Thus allergic reactions to streptokinase do not seem to be a major clinical problem. However, the potential failure of thrombolysis due to streptokinase antibodies remains a concern.

Most patients presenting to coronary care units have circulating streptokinase antibodies, though at a low titre. ${ }^{34}$ After administration of streptokinase the antibody titre, which is mainly IgG, initially falls and subsequently rises after day 3-4 to reach high values by day $7-10 .^{34}$ Initially it was thought that this high value was maintained for only two or three months. The recommendation was that streptokinase could be readministered six months after the previous dose, when one study suggested that anti-streptokinase activity was negligible. ${ }^{5}$ Six other studies (one as yet unpublished), however, reported that titres of streptokinase antibodies remained high for much longer. Antibody titres, theoretically capable of neutralising a complete dose $\left(1.5 \times 10^{6}\right.$ units $)$ of streptokinase, have been found at eight months, ${ }^{6}$ a year, ${ }^{4}$ two years, ${ }^{48}$ three years, ${ }^{9}$ and four years, ${ }^{9}$ after treatment. On page 119 of this issue of the British Heart fournal Patel et al report that streptokinase antibodies were high for up to 866 days after the initial dose. There is no reason to believe that streptokinase antibodies disappear even after three of four years, it is just that they have not been looked for.

Most studies of the immune reaction provoked by streptokinase have not merely measured antibody titres. Functional assays to assess the ability of these antibodies to counter the thrombolytic effects of streptokinase have shown that high titres of antibodies are associated with significant in vitro neutralisation of streptokinase activity. These functional assays include the neutralisation titre, which measures the ability of the patient's serum to prevent clot lysis by a standard dose of streptokinase in a test tube and fibrin plate lysis, which measures the ability of the patient's serum to inhibit the lysis by streptokinase of a fibrin impregnated plate. From these assays it is possible to calculate an amount of streptokinase antibody that will inhibit totally a standard administered dose. About two thirds of patients will have streptokinase antibody titres of this level for up to four years. ${ }^{69}$ Patel et al, however, found a moderate decrease with time. All these studies, however, suggest that high neutralising antibody titres will be found in a considerable number of patients if they are caught more than six months after the initial dose. Though streptokinase antibodies persist for many years and suppress in vitro thrombolysis it is not known whether these antibodies inhibit the activity of streptokinase given to patients in the coronary care unit. Evidence from a rabbit model supports the concept that these antibodies have a clinical role. ${ }^{10}$ Compared with rabbits that had never received streptokinase thrombolysis of surgically induced external jugular thrombosis was significantly impaired in rabbits treated with streptokinase a month before. The pre-treated rabbits had high titres of streptokinase antibodies. Similar compelling evidence in humans is not available.

There is evidence, though it is not conclusive, that streptokinase antibodies do inhibit streptokinase activity in humans. The standard dose of $1.5 \times 10^{6}$ units dose of streptokinase was not chosen because of dose response studies of mortality, left ventricular function, or vessel patency. It was chosen to overcome the streptokinase antibodies found in most people because of streptococcal infection and to cause a lytic state as measured by haematological variables. ${ }^{11}$ A lytic state will develop at this dose in more than $97 \%$ of people though the variation of dose required is wide ( $3 \times 10^{5}-1.25 \times 10^{6}$ units). Smaller doses will not produce a lytic state in all patients because of the persisting antibodies. Furthermore, smaller doses given to patients with arterial thrombosis did not produce a lytic state in those with high antibody titres. ${ }^{12}$ The arterial thrombi were not lysed in these patients. ${ }^{12}$ This study was small and not controlled, but it is further evidence that streptokinase antibodies may cause failure of thrombolysis in vivo. Two studies of thrombolysis have shown that the streptokinase antibody titre does not affect 90 minute coronary artery patency rates when 1.5 $\times 10^{6}$ units of streptokinase are given to patients who have not had streptokinase before. ${ }^{13} 14$ This indicates that small amounts of naturally occurring antibodies are not important when current dosing regimens are used. The antibody titre in response to administered streptokinase, however, persists at a level many times that of the naturally occurring antibodies for at least four years.

There are several strategies for overcoming the potential effect of streptokinase antibodies when streptokinase 
is required a second time. Increased doses of streptokinase capable of overcoming the antibodies but still leaving enough active streptokinase to cause a lytic state could be administered. Unfortunately the titres of antibodies vary greatly with time and from patient to patient. A standard repeat dose could not be used without risking a failure of thrombolysis in patients with very high antibody titres and a risk of haemorrhage in patients with low antibody titres. A second strategy would measure the antibody titre in patients. This could be done regularly in the outpatient department with the patient keeping the result with them in the same way as they keep an INR card. The appropriate dose of streptokinase could be calculated if the patient was subsequently admitted. Alternatively a rapid bedside antibody test could be devised to screen out those patients with high antibody levels on admission to coronary care unit. An alternative agent could be administered to such patients. Another solution would be to give all patients who might have high streptokinase antibodies a thrombolytic agent not affected by these antibodies - currently, this would have to be alreplase (tissue plasminogen activator). All these potential solutions would considerably increase the cost of thrombolytic therapy.

Thus there is evidence from in vitro and animal studies and circumstantial clinical evidence to suggest that the immune response to an administered dose of streptokinase may inhibit a second dose for many years. A clinical trial is needed to test whether this is a real clinical problem. It is impractical to have a large mortality trial of thousands of patients but a smaller trial using a surrogate end point such as 90 minute coronary artery patency or left ventricular function is urgently required. In the meantime we have evidence that a form of treatment that has been shown conclusively to benefit patients with acute myocardial infarction and has been adopted by coronary care units around the world may be ineffective in a subgroup of patients - that is those having streptokinase for a second time. It seems sensible not to re- administer streptokinase until the immune response is shown to be of theoretical but not practical importance.

MAURICE B BUCHALTER

Department of Cardiology,

University Hospital of Wales, Heath Park, Cardiff

1 White HD, Cross DB, Williams BF, Norris RM. Safety and efficacy of repeat thrombolytic treatment after acute myocardial infarction. $B r$ repeat thrombolytic tre

2 ISIS-2 (second International Study of Infarct Survival) Collaborative Group. Randomised trial of intravenous streptokinase, oral aspirin, both or neither among 17187 cases of suspected myocardial infarction. Lancet 1988;ii:349-60.

3 Lynch M, Littler WA, Pentecost BL, Stockley RA. Immunoglobulin response to intravenous streptokinase in acute myocardial infarction. $\mathrm{Br}$ Heart $\mathcal{F}$ 1991;66:139-42.

4 Buchalter MB, Suntharalingam G, Jennings I, Hart C, Luddington RJ, Chakraverty $\mathrm{R}$, et al. Streptokinase resistance: when might streptokinase be ineffective? Br Heart $\mathcal{F}$ 1992;68:449-53.

5 Fears R, Ferres H, Glasgow E, Standring R, Hogg KJ, Gemmill JD, et al. Monitoring of streptokinase resistance titre in acute myocardial infarction patients up to 30 months after giving streptokinase or anistreplase and related studies to measure specific antistreptokinase IgG. Br Heart $f$ 1992;68:167-70.

6 Jalihal S, Morris GK. Antistreptokinase titres after intravenous streptokinase. Lancet 1990;335:184-5.

7 Massel D, Turpie AG, Cairns JA, Gill JB, O’Dell C, Russett J. Persistence of neutralising antibodies at 1 year following intravenous streptokinase for acute myocardial infarction [abstr]. Circulation 1990;82:(suppl III)for acute.

8 Lee HS, Cross S, Davidson RJC, Reid T, Jennings K. When is it safe to readminister streptokinase? Measurement of anti streptokinase antibodies and neutralisation titres [abstr]. Scott Med f 1992;37:93.

9 Elliot JM, Cross DB, Cederholm-Williams S, White HD. Streptokinas titers 1 to 4 years after intravenous streptokinase. Circulation 1991;81 II-116.

10 Massel DM, Turpie AGG, Cairns JA, Ofosu FA, Buchanan MR. Previou streptokinase therapy inhibits subsequent streptokinase thrombolysis. Circulation 1991;84(suppl II)-467.

11 Verstaete M, Vermylen J, Amery A, Vermylen C. Thrombolytic therapy with streptokinase using a standard dosage scheme. $\mathrm{Br} \mathrm{Med}$ 1966;i:454-6.

12 James DCO. Antistreptokinase levels in various hospital patients groups. Postgrad Med f 1973;49(suppl):26-9.

13 Fears R, Hearn J, Standring R, Anderson JL, Marder VJ. Lack of influence of pretreatment antistreptokinase antibodies on efficacy on a multicenter patency comparison of intravenous streptokinase and anistreplase in acute myocardial infarction. Am Heart $\mathcal{F} 1992 ; 124$ 305-14.

14 Gemmill JD, Hogg KJ, Burns JMA, Standring R, Greenwood H, Fears R et al. Lack of relation of pretreatment streptokinase resistance titres and streptokinase IgG concentrations with hypotensive responses and coronary patency with thrombolytic agents containing streptokinase [abstr] Br Heart $\mathcal{1}$ 1990;64:50. 